\title{
Akibat Hukum Dissenting Opinion terhadap Putusan Pengadilan dalam Perkara Tindak Pidana Korupsi
}

\author{
Susiana Kifli* \\ Fakultas Hukum Universitas Muhammadiyah Palembang \\ *Correspondence email: susianakifli@gmail.com
}

\begin{abstract}
Abstrak. Pengadilan tindak pidana korupsi yang terbentuk berdasarkan UU No. 46 Tahun 2009, dalam praktik telah menerapkan banyak putusan yang diputus dengan melakukan Dissenting Opinion, Hal ini menyinggung situasi Pengadilan Tindak Pidana Korupsi sebagai badan eksekutif hukum yang tidak lazim yang masih bergantung pada Undang-Undang tentang Kekuatan Hukum yang mengizinkan pertimbangan Dissenting Opinion, atau lagi-lagi bagi hakim yang memiliki berbagai perasaan, mereka dapat mengingat sudut pandang mereka terhadap pilihan sebagai substansi pilihan pada kasus pencemaran nama baik. Isu-isu yang dibicarakan dalam proposisi ini adalah: Apa hasil yang sah dissenting opinion pada pilihan pengadilan dalam kasus pencemaran nama baik. Pemeriksaan ini merupakan eksplorasi yang sah dengan metodologi yuridis regularisasi sebagai metodologi fundamental dalam menyelidiki bahan-bahan yang halal. Mengingat konsekuensi dari eksplorasi dan percakapan, akhir yang menyertainya dapat ditarik: Dampak Penggunaan yang Sah dissenting opinion pada Putusan Majelis Hakim sejak diberlakukannya Undang-Undang Nomor 4 Tahun 2004 tentang Kekuasaan Kehakiman, ada pertunjukan di antara individu-individu dari dewan hakim di mana jika dalam rapat konsultasi dewan hakim tidak tercapai kesepakatan, penilaian minoritas memutuskan yang bervariasi dari konsekuensi dari pertemuan musyawarah hakim harus diingat untuk pilihan dan merupakan bagian tak terpisahkan dari pilihan. Dissenting opinion juga dapat digunakan sebagai bahan pemikiran untuk diputuskan pada banding maupun kasasi.
\end{abstract}

Kata Kunci: disenting opinion; korupsi

\begin{abstract}
The corruption court which was shaped dependent on Law No. 46 of 2009, practically speaking has applied numerous choices chosen by leading Disagreeing Assessment, this alludes to the situation of the Debasement Court as an uncommon court actually dependent upon the Legal Force Act which permits Contradicting Assessment, or for judges who have various conclusions can contain his viewpoint in the choice was the substance of the choice looking into it of a criminal demonstration of defilement. The issues talked about in this paper is: What is the lawful impact of disagreeing assessment on court choices in instances of defilement? This examination is a legitimate exploration with standardizing juridical methodology as the primary methodology in investigating lawful material. In view of the consequences of the examination and conversation, the accompanying ends can be drawn: 1). Because of the utilization of the contradicting assessment to the Adjudicators' choice since the authorization of Law Number 4 of 2004 concerning Legal Force, there is a show among individuals from a board of judges where if in a pondering meeting the board of judges isn't arrived at agreement, the assessment of a minority judge not the same as the consequence of a legal gathering should be remembered for the choice and is a section which is indivisible from the choice. Contradicting feelings can likewise be utilized as thought for decided at the allure and cassation level.
\end{abstract}

Keywords: dissenting opinion; corruption

\section{PENDAHULUAN}

Undang-Undang No. 31 Tahun 1999 tentang Pemberantasan Tindak Pidana Korupsi, juncto UndangUndang Nomor 20 Tahun 2001 Pasal 2 menentukan:

(1) Setiap orang barang siapa secara melawan hukum mengajukan demonstrasi memajukan diri sendiri atau orang lain atau suatu perusahaan yang dapat merugikan keuangan negara atau perekonomian negara, ditentang dengan penahanan untuk selamalamanya atau penahanan paling sedikit 4 (empat) kali untuk waktu yang lama dan paling lama 20 tahun dan denda pokoknya Rp. 200.000.000,00 dan limit sebesar Rp. 1.000.000.000,00.

(2) Dalam hal tindak pidana korupsi sebagaimana disinggung dalam ayat (1) selesai dalam kondisi tertentu, hukuman mati dapat dipaksakan.
Keadaan tertentu dalam ketentuan Pasal 2 Undang-Undang No. 31 Tahun 1999 juncto UndangUndang Nomor 20 Tahun 2001 direncanakan sebagai pemberat bagi pelaku tindak pidana demonstrasi pencemaran nama baik apabila perbuatan tersebut dilakukan pada saat negara dalam keadaan bahaya menurut undang-undang yang bersangkutan, pada saat peristiwa bencana publik, sebagai pengulangan dari demonstrasi kriminal kehinaan. atau sekali lagi ketika negara berada dalam kondisi darurat keuangan dan terkait uang. (Suradi, 2011)

Dengan hadirnya UU No: 31 Tahun 1999 yang telah dikoreksi dengan UU No: 20 Tahun 2001, diyakini akan benar-benar ingin memenuhi dan mengharapkan perbaikan hukum lokal untuk mencegah dan menghancurkannya dengan lebih sukses. Segala bentuk kekotoran batin yang sangat menghambat Uang Negara atau perekonomian negara secara khusus dan meliputi 
wilayah setempat secara keseluruhan disebut perbuatan yang tidak biasa.

Secara praktis, hampir semua pilihan dicapai melalui pertimbangan dan kesepakatan, jika ada perbedaan penilaian, pilihan ditunda untuk diteliti kembali oleh semua individu dari dewan hakim, dan harus dimungkinkan secara umum. Jika setelah direnungkan berkali-kali masih terdapat perbedaan penilaian, maka diputuskan (semua orang) dengan mencatat berbagai dugaan dan menyerahkannya kepada pengurus Pengadilan Tinggi atau direktur pengadilan sebagai laporan. Dalam kondisi tertentu pilihan tersebut disetujui untuk mengikuti penilaian dari direktur perkumpulan, pengaturan dengan memperhatikan perbedaan, selain hanya setelah keinginan dari penyelenggara pertemuan sangat jarang terjadi. Terlepas dari apakah penilaian eksekutif pertemuan diikuti, itu semata-mata merupakan hasil dari perselisihan yang membujuk individu yang berbeda.

Dalam memutuskan suatu kesimpulan akhir, dalam hal terdapat penilaian yang tidak setuju, pilihan diambil berdasarkan suara terbanyak dan harus diingat pilihannya, sesuai Undang-Undang Nomor 5 Tahun 2004 tentang Perubahan atas Undang-Undang Nomor 14 Tahun 1985 yang disahkan oleh DPR-RI pada Desember 2003, memuat pasal 19:

Ayat 4: Dalam sidang pertimbangan, masing-masing hakim wajib mengajukan pertimbanganpertimbangan yang tersusun atau dugaan-dugaan yang sedang dikerjakannya untuk diperiksa dan menjadi bagian pilihan yang tidak dapat dibedakan.

Ayat 5: Jika pertemuan pertimbangan tidak dapat mencapai kesepakatan yang konsisten, penilaian dari berbagai otoritas yang ditunjuk harus diingat untuk pilihan.

Dua isu utama yang muncul dari penggunaan Dissenting Opinion dalam kasus demonstrasi kriminal kekotoran batin, khususnya: (1) Pelanggaran kehinaan telah diatur sebagai kesalahan yang tidak biasa, harus dicegah dengan aktivitas yang belum pernah terjadi sebelumnya, namun dengan penggabungan penilaian alternatif yang sah dalam pilihan atas kesalahan pencemaran nama baik, dapat melemahkan salah satu tujuan hukum, yaitu kepastian hukum khusus bagi terpidana pencemaran nama baik yang dipandang bertanggung jawab oleh sebagian besar hakim. (2) Bahan hukum acara di Pengadilan Tipikor adalah hukum acara yang bergantung pada pengaturan KUHAP, sedangkan Pasal 182 ayat 6 dan pasal 7 tidak mempersepsikan adanya Dissenting Opinion sebagai berbagai sentimen yang mungkin timbul. dimasukkan sebagai diakui "eksekusi dinamis dicatat dalam banyak pilihan yang dibuat secara eksplisit untuk alasan ini dan substansi buku bersifat pribadi." Ini menyiratkan bahwa sekali lagi pertimbangan Kesimpulan yang Bertentangan dalam kasus-kasus penurunan nilai tidak diperbolehkan. Dari kedua masalah hukum tersebut, dengan tujuan agar tujuan definitif dalam tinjauan ini adalah untuk memutuskan situasi Dissenting Opinion dalam perkara tindak pidana korupsi.

\section{METODE}

Penelitian ini merupakan pemeriksaan yuridis yang mengatur atau pemeriksaan doktrinal. Eksplorasi diarahkan dengan memeriksa atau mengikuti pengaturan yang mengidentifikasi dengan situasi Dissenting Opinion dalam kasus tindak pidana korupsi, sesuai dengan undang-undang dan pedoman yang relevan.

\section{HASIL DAN PEMBAHASAN}

\section{Akibat Hukum Dissenting Opinion Terhadap Putusan Pengadilan Dalam Perkara Tindak Pidana Korupsi}

Pada umumnya dissenting opinion atau penilaian yang kontras pada pilihan dewan hakim hanya dikenal di negara-negara yang berpegang teguh pada perangkat hukum umum Saxon Inggris Kuno seperti AS dan Inggris. Ajudikator yang akan memberikan dissenting opinion benar-benar berusaha untuk memberikan jawaban yang sah terhadap suatu perkara dengan membentuk pilihan yang dianggap dapat memberikan rasa keadilan kepada termohon. Dissenting opinion tersebut kemudian digunakan sebagai catatan penting pada duplikat pilihan dan disimpan sebagai arsip rahasia oleh pengadilan.

Pemerataan harus mempertimbangkan realitas saat ini di awal, pedoman hukum yang benar-benar telah diabaikan dan terutama dalam kasus-kasus pidana yang tidak biasa atau kasus-kasus pidana yang pada umumnya akan menjadi baru. Kondisi majelis hakim yang tidak dapat didamaikan dapat menjadi pemicu dissenting opinion baik dilihat dari perbedaan standar masingmasing hakim dalam menerima mentalitas sejauhmana tingkat informasi dan kemampuan memberikan pilihan yang berkualitas. Nantinya, setiap pilihan majelis hakim di Indonesia yang disandingkan dengan penilaian yang kontradiktif, hendaknya mendapat pertimbangan luar biasa dari Komisi Hukum Republik Indonesia. Mengingat rangkaian hukum kita secara keseluruhan adalah daratan Eropa. Ekuitas tidak bisa palsu, kebenaran itu terang-terangan dan keduanya adalah hak istimewa masing-masing individu. (Ahmad Rifai, 2010)

Untuk dissenting opinion ini, rencananya dapat ditemukan dalam Pasal 14 Undang-Undang Nomor 48 Tahun 2009 tentang Kekuasaan Kehakiman lebih spesifik: Pilihan diambil tergantung pada pertemuan pemikiran pribadi para hakim.

1. Dalam sidang permusyawaratan, setiap hakim wajib mengajukan renungan-renungan atau anggapananggapan yang tersusun atas persoalan yang sedang 
dianalisa dan menjadi bagian pilihan yang tidak dapat dipisahkan.

2. Jika pertemuan musyawarah tidak dapat mencapai kesepakatan yang konsisten, penilaian otoritas alternatif yang ditunjuk harus diingat untuk pilihan tersebut.

3. Pengaturan lebih lanjut dengan memperhatikan rapat pertimbangan sebagaimana dimaksud pada ayat (2) dan ayat (3) diatur dalam Pedoman Pengadilan Tinggi.

Maka pada saat itu mengenai dissenting opinion dalam penilaian tingkat kasasi, sangat baik dapat ditemukan dalam Pasal 30 Undang-Undang Nomor 14 Tahun 1985 tentang MA sebagaimana telah dikoreksi dengan Undang-Undang Nomor 5 Tahun 2004 tentang Perubahan Undang-Undang Nomor 14 Tahun 1985 tentang MA dan kemudian direvisi untuk kedua kalinya dengan Undang-Undang Nomor 3 Tahun 2009 tentang Perubahan Kedua Atas Undang-Undang Nomor 14 Tahun 1985 tentang MA ("UU MA"):

1. Dalam pertemuan sidang permusyawaratan, masingmasing otoritas yang ditunjuk tak tertandingi berkomitmen untuk menyerahkan pemikiran atau penilaian yang disusun untuk dianalisis dan menjadi bagian pilihan yang tak terpisahkan.

2. Jika pertemuan musyawarah tidak dapat mencapai kesepakatan yang konsisten, penilaian hakim Pengadilan Tinggi yang khas harus diingat untuk pilihan.

Undang-Undang Nomor 4 Tahun 2014 tentang Penetapan Undang-Undang Tidak Resmi Pengganti Undang-Undang Nomor 1 Tahun 2013 tentang Perubahan Kedua Atas Undang-Undang Nomor 24 Tahun 2003 tentang Mahkamah Konstitusi Menjadi Undang-Undang menjadi Undang-Undang juga mengatur berbagai penilaian pejabat yang ditunjuk yang mapan dalam memutus. Jika seluruh pertemuan yang membahas setelah upaya yang sungguh-sungguh tidak dapat mencapai kesepakatan yang konsisten, pilihan diambil dengan suara terbanyak. Jika kesepakatan yang konsisten tidak tercapai, penilaian dari berbagai individu dari Dewan Juri akan diingat sebagai pilihan. (Laica Marzuki, 2000)

Hal yang sama juga disampaikan oleh Hakim Tinggi Sebelumnya Djoko Sarwoko dalam artikel berjudul Dissenting Opinion di Mata Mantan Hakim Agung, secara konsep, dissenting opinion merupakan penilaian alternatif dari bagian yang lebih besar. Pada mulanya dissenting opinion dan concurring opinion dikenal dalam keseluruhan rangkaian undang-undang negara hukum berbasis adat. Mulai sekitar tahun 2004, Indonesia telah menganutnya dalam UU Kekuatan Hukum dan UU MA. Dissenting opinion telah berbeda sejak awal. Mulai dari kenyataan yang sah, perenungan yang halal, hingga keputusan yang bersifat unik. Untuk concurring opinion, realitas yang sah adalah sesuatu yang sangat mirip, perenungan adalah sesuatu yang sangat mirip, namun keputusannya unik.

Selain itu, Djoko Sarwoko menjelaskan, jika dalam perkara pidana yang dilakukan oleh lima pengurus, dua pejabat yang ditunjuk menyatakan bahwa dakwaan pembantu itu dibuktikan, satu penting, dan dua lainnya dibebaskan, Karena satu otoritas yang ditunjuk menggunakan berbagai dissenting opinion. Sebab, Setara berlaku dalam situasi di mana biaya penting pertama dan tambahan kedua digunakan. Jika dua hakim menyatakan bahwa tuntutan pokok yang pokok terbukti, satu pejabat yang ditunjuk menunjukkan tuntutan pokok berikutnya, dan dua hakim yang berbeda menyatakan berhenti, maka, pada saat itu, satu hakim disusun sebagai penilaian kategori dissenting opinion.

Djoko menambahkan, dasar penegasan kerangka keadilan pidana kita adalah penuntutan. Dalam hal muatannya unik, signifikansinya tidak sama dengan awalnya. Padahal faktanya keduanya sama-sama tercela, namun ketika reaksi terhadap dakwaan itu unik, itu dianggap sebagai penilaian yang tidak setuju mengingat dakwaannya unik. Terlepas dari apakah ada tiga anggapan yang tidak setuju, pertemuan tetap dapat memutuskan. Cobalah untuk tidak membiarkan perasaan yang bertentangan menghalangi dinamika. Dalam sistem yang berlaku di Pengadilan Tinggi, misalnya, dapat ditambahkan Hakim untuk pengadilan tertinggi jika perkara tersebut tidak dapat dipilih karena terdapat penilaian yang dissenting opinion.

\section{Contoh Putusan Dissenting Opinion}

Sebagai contoh dapat kita lihat dalam Putusan Pengadilan Negeri Bulukumba Nomor 150/ Pid.B/2013/PN.BLK, yang menyatakan bahwa termohon telah terbukti bersalah secara sah dan meyakinkan karena melakukan perbuatan salah "pemerasan sebagai demonstrasi yang terus menerus". Kemudian pada saat itu majelis hakim menjatuhkan hukuman kurungan kepada penggugat selama 8 (delapan) bulan. Dalam pertimbangannya, hakim menilai bahwa perbuatan yang dilakukan oleh termohon merupakan perbuatan salah yang sebenarnya ada hubungannya dengan kesalahan masa lalu yang telah diucapkan dibuktikan dalam suatu pilihan pengadilan yang mempunyai kekuatan hukum super tahan lama. Jadi itu harus dilihat sebagai demonstrasi terus menerus, bukan pengulangan atau pelanggaran aturan ne bis in idem. Dengan demikian, dalam pemikiran dewan hakim terdapat dissenting opinion mengenai penafsiran asas hukum ne bis in idem dan hak keperdataan saksi korban oleh Hakim Anggota II Bambang Supriyono, S.H.

Contoh lain dapat kita lihat dalam Putusan Mahkamah Konstitusi Nomor 21/PUU-XII/2014 tentang Pengujian Undang-Undang Nomor 8 Tahun 1981 tentang Hukum Acara Pidana mengenai penerjemahan bukti primer yang memadai dan kepastian tersangka 
sebagai objek praperadilan. Majelis hakim mengungkapkan ungkapan "pembuktian permulaan", "pembuktian yang cukup mendasar", dan "pembuktian yang cukup" dalam Pasal 1 angka 14, Pasal 17, dan Pasal 21 ayat (1) Undang-Undang Nomor 8 Tahun 1981 tentang Hukum Acara Pidana ("KUHAP") bertentangan dengan Undang-Undang Dasar Negara Republik Indonesia Tahun 1945 ("UUD 1945") dan tidak mempunyai kekuatan hukum yang membatasi sepanjang tidak kurang dari dua alat bukti menurut Pasal 184 KUHP. Kemudian pada saat itu terhadap kepastian tersangka, majelis hakim menyatakan bahwa Pasal 77 huruf a KUHAP bertentangan dengan UUD 1945 dan tidak mempunyai kekuatan hukum yang membatasi sepanjang tidak diuraikan termasuk jaminan tersangka, penggeledahan dan penyitaan. Pilihan ini tidak diambil secara konsisten dengan alasan ada dissenting opinion (pendapat berbeda) dan concurring opinion (alasan berbeda). Dari 9 (sembilan) hakim konstitusi, 3 (tiga) hakim konstitusi mengajukan dissenting opinion yakni I Gede Dewa Palguna, Muhammad Alim, dan Aswanto. Sementara 1 hakim kontitusi mengajukan concurring opinion yaitu Patrialis Akbar.

Dissenting opinion sudah cukup lama dikenal di ranah pemerataan di Indonesia. Apa yang tidak ada saat itu adalah kebutuhan untuk mengingatnya untuk pilihan. Sampai saat ini, penilaian yang bertentangan telah diingat untuk sebuah buku yang jarang diberikan dan diawasi oleh pengadilan secara sembunyi-sembunyi. Dalam buku ini, nama-nama juri yang kontras dalam penilaian, situasi mereka di dewan, nomor kasus, tanggal pilihan, kesimpulan dan alasan dimasukkan. (Mahkamah Agung RI, 2010)

Dissenting opinion biasanya disertakan menjelang akhir pilihan setelah sebagian besar pilihan. Cara berpikir adanya undang-undang penilaian yang kontradiktif adalah dengan memberikan tanggung jawab terhadap pemerataan mencari daerah dari pejabat yang ditunjuk yang memilih perkara. Seperti diketahui, sebagian besar sengketa hukum dipilih oleh dewan yang terdiri dari setidaknya tiga hakim.

Adanya dissenting opinion demikian pula mempengaruhi bekerja pada sifat hukum (SDM), terutama diputuskan melalui alasan dan gambaran yang dicatat dalam penilaian yang bertentangan, masyarakat umum, khususnya para ahli dan penggemar hukum, dapat mensurvei sifat ilmu pengetahuan dan luas pemahaman dari otoritas yang ditunjuk terkait. secara eksplisit untuk pengadilan yang ketat. Mengingat bahwa sebagian besar hukum materil belum ditetapkan dalam fiqh yang secara tegas diidentikkan dengan kontras penilaian, seperti halnya penguatan tuntutan kemajuan manusia yang memerlukan evaluasi ulang pelajaran yang ketat (Muhammad Said Al-Asnawi, 2005). Dengan demikian, penggabungan penilaian tidak setuju akan memberikan pemenuhan moral kepada hakim untuk dapat diandalkan secara terpisah dan sekaligus cukup sulit bagi mereka untuk terus bekerja pada diri mereka sendiri.

Ada sumber penilaian yang kontradiktif dalam Undang-Undang Nomor 48 Tahun 2009 terkait dengan Undang-Undang Nomor 4 Tahun 2004 tentang Kekuatan Hukum yang mengatur tentang perhimpunan kekuatan hukum. Dalam beberapa kasus di pengadilan tingkat pertama dan Pengadilan Tinggi, kerangka penilaian yang bertentangan telah diterapkan. Berbagai perasaan diingat untuk pilihan dan diletakkan setelah perenungan yang menyusun premis pilihan. Meski ada penilaian yang kontradiktif, pilihan tersebut tetap disahkan oleh direktur dan semua individu dari pertemuan, termasuk mereka yang memiliki sentimen berbeda.

Sepanjang adanya pembicaraan tersebut, salah satu akibat dari pembicaraan materi Rancangan UndangUndang tentang Kekuatan Hukum (yang kemudian menjadi Undang-Undang Nomor 4 Tahun 2004 tentang Kekuasaan Kehakiman/ sekarang UU No. 48/ 2009) adalah pemekaran. substansi baru sehubungan dengan "Berbagai Perspektif Otoritas yang Ditunjuk" (Dissenting Opinion). Adapun maksud dari penggabungan substansi ini adalah: “... Dalam sistem pengawasan batin di dalam badan eksekutif hukum sebagai tahapan untuk memperoleh pejabat yang ditunjuk yang berkualitas, bermoral, dan berbakti luar biasa dalam menyelesaikan kewajibannya, dan berkenaan dengan manajemen luar, untuk menjadi khusus sehingga orang pada umumnya memahami pilihan perkara yang diberikan kepada mereka tergantung pada perenungan atau penilaian tersusun yang diberikan oleh hakim yang menganalisis perkara di pengadilan pendahuluan".

Dalam pergantian peristiwanya, berdasarkan peraturan perundang-undangan dan pedoman di bidang kekuatan hukum, pejabat yang ditunjuk (minoritas) yang tidak dapat membantu bertentangan dengan dampak dari pertemuan konsultasi hakim dapat memasukkan Dissenting Opinion dalam (Terlebih lagi, berubah menjadi bagian mendasar dari) pilihan pengadilan. Dissenting Opinion dapat dianggap sebagai salah satu standar sifat pilihan pengadilan dalam memenuhi rasa keadilan daerah setempat dengan adanya komponen Dissenting Opinion kemudian, pada saat itu, masyarakat umum dapat mengevaluasi sifat pemikiran masingmasing hakim dan mengetahui "pola pikir internal" yang terjadi selama pertemuan pertimbangan hakim yang merupakan salah satu tahap vital di bawah tatapan mantap dari pilihan pengadilan yang dibuat.

Dengan pengaturan sehubungan dengan Dissenting Opinion dalam undang-undang dan pedoman di bidang kekuatan hukum dari satu sudut pandang yang memperhitungkan perbedaan penilaian (transparan) antara individu dari majelis hakim dan pengaturan KUHAP kemudian lagi yang tidak memungkinkan hal ini menyebabkan ketidakselarasan antara peraturan perundang-undangan dan pedoman yang diidentikkan 
dengan kaidah standar kekuatan hukum dengan kaidah pelaksanaan hukum acara pidana (KUHAP), terutama mengenai sifat dan cara penyampaian perbedaan penilaian antara individu-individu dari majelis hakim dalam kerangka keadilan (penjahat) di Indonesia.

$$
\text { Penerapan Dissenting Opinion Karena }
$$

demonstrasi pidana pencemaran nama baik, tidak menghilangkan perwujudan pembunuhan kehinaan, mengingat meskipun ada oknum majelis hakim yang mengajukan berbagai dugaan, termohon tidak segera dibersihkan, dengan alasan bahwa dalam memutuskan, mereka benar-benar mengacu pada penilaian sebagian besar dewan hakim.

\section{SIMPULAN}

Berdasarkan uraian pembahasan sebelumnya, maka yang dapat ditarik kesimpulan bahwa: Akibat Hukum Penerapan dissenting opinion pada Putusan Majelis Hakim sejak diberlakukannya Undang-Undang Nomor 4 Tahun 2004 tentang Kekuasaan Kehakiman, ada pertunjukan di antara individu-individu dari dewan hakim di mana jika dalam rapat konsultasi dewan hakim tidak tercapai kesepakatan, penilaian minoritas memutuskan yang bervariasi dari konsekuensi dari pertemuan musyawarah hakim harus diingat untuk pilihan dan merupakan bagian yang tak terpisahkan dari pilihan. Juga, catatan sehubungan dengan penilaian tidak setuju dapat dipikirkan pada tingkat banding dan Kasasi.

\section{DAFTAR PUSTAKA}

Ahmad Rifai. 2010. Penemuan Hukum oleh Hakim. Jakarta: Sinar Grafika

Laica Marzuki. 2000. "Sudah Waktunya Putusan MA Memuat Dissenting Opinion". Jakarta: Kompas

Mahkamah Agung RI, Pedoman Pelaksanaan Tugas dan Administrasi Pengadilan, Buku II edisi revisi, (Jakarta: Reedbox Publisher diterjemahkan oleh Muhammad Iqbal S.Hi., MA, 2010),103.

Muhammad Saìd Al-Asnawi, al syari`h al-isla>miyah wa al qanu>n al-mishri, alih bahasa: Saiful Ibad: Problematika Dan Penerapan Syariat Islam dalam Undang-Undang, (Jakarta: Gaung Persada, 2005), 60.

Suradi, Tindak Pidana Korupsi, Prenada Media Group, Jakarta, 2011, hlm. 13. 